\title{
The Purification and Properties of an Aryl $\beta$-Hexosidase from Bovine Liver ${ }^{1}$
}

\author{
JACK J. DISTLER AND GEORGE W. JOURDIAN

\begin{abstract}
Rackham Arthritis Research Unit and Department of Biological Chemistry, University of Michigan, Ann Arbor, Michigan 48109
\end{abstract}

Received July 15, 1976

\begin{abstract}
An aryl $\beta$-hexosidase was purified 800 -fold from bovine liver. The purified enzyme hydrolyzed $p$-nitrophenyl glycosylpyranoside derivatives of $\beta$-D-galactose, $\beta$-D-glucose, $\beta$-D-xylose, $\beta$-D-mannose, and $\alpha$-L-arabinose, but did not hydrolyze several other $p$ nitrophenyl glycosides. The enzyme also catalyzed hydrolysis of a variety of plant arylglucosides. Disaccharides, polysaccharides, glycolipids, glycoproteins, and glycosaminoglycans containing terminal nonreducing $\beta$-D-galactopyranosyl or $\beta$-D-glucopyranosyl residues were not hydrolyzed. The $\mathrm{pH}$ optima for the several substrates tested ranged from 7.0 to 9.5. The purified enzyme was homogeneous by disc gel electrophoresis and had a molecular weight of 41,000 by Sephadex gel filtration and 16,000 by disc gel electrophoresis performed in the presence of sodium dodecyl sulfate. The enzyme readily transferred glycosyl residues from susceptible $\beta$-galactosides or $\beta$-glucosides to other sugars; the resulting products were not hydrolyzed by the enzymc. Methyl $\alpha$-D-glucopyranoside was the most efficient carbohydrate acceptor compound tested. The enzyme exhibited a $K_{m}$ for $p$-nitrophenyl $\beta$-D-galactopyranoside of $1.78 \times 10^{-3} \mathrm{M}$ and for $p$ nitrophenyl $\beta$-D-glucopyranoside, $2.50 \times 10^{-3} \mathrm{M}$ when incubations were conducted in the presence of $0.15 \mathrm{~m}$ methyl $\alpha$-D-glucopyranoside. Aryl $\beta$-hexosidase was found in the cytosol of all mammalian livers tested, but could not be detected in liver of birds, reptiles, or fish; low levels were detected in frog liver. Analysis of bovine extracts indicated that the enzyme occurred in liver, kidney, and intestinal mucosa; it was not detected in testis, spleen, serum, or muscle.
\end{abstract}

Two types of $\beta$-galactosidases capable of hydrolyzing $p$-nitrophenyl $\beta$-D-galactopyranoside ( $p$-NP $\beta \mathrm{Gal})^{2}$ were reported in bovine and human liver $(1,2)$. One enzyme (Type I) was bound to phenylthio- $\beta$ Galsubstituted agarose and exhibited a broad

\footnotetext{
${ }^{1}$ This work was supported in part by Grant AM 10531 from the National Institutes of Health, and by a grant from the Arthritis Foundation, Michigan Chapter.

"Abbreviations used: $p$-NP- $\beta$ GlcNAc, $p$-nitrophenyl 2-acetamido-2-deoxy- $\beta$-D-glucopyranoside; - $\beta$ GalNAc, -2 -acetamido-2-deoxy- $\beta$-D-galactopyranoside; - $\beta \mathrm{Gal}, \beta$-D-galactopyranoside; $-\beta \mathrm{Glc},-\beta$-D-glucopyranoside; $-\alpha$ Ara, $-\alpha$-L-arabinopyranoside; $-\beta \mathrm{Xyl}$, $-\beta$-D-xylopyranoside; $\quad-\alpha$ Fuc, $\quad-6$-deoxy- $\alpha$-L-galactopyranoside; esculin, 6,7-dehydrocoumarin-6-O $\beta$-D-glucopyranoside; salicin, salicyl alcohol $2-O-\beta$ D-glucopyranoside; phloridzin, 4,6-dehydroxy-2-O[ $\beta$-D-glucopyranoside- $\beta$ - $(p$-hydroxy phenyl)]-propiophenone; CM, carboxymethyl; DEAE, diethylaminoethyl; uv, ultraviolet. Unless otherwise indicated, all sugars are of the $\mathbf{D}$ configuration.
}

substrate specificity. A second $\beta$-galactosidase (Type II), observed to pass through this affinity support, was characterized by a lower molecular weight and a higher $\mathrm{pH}$ optimum ( $\mathrm{pH} 6$ to 9). The latter enzyme hydrolyzed aryl $\beta$-galactosides (1) and aryl $\beta$-glucosides (2).

Mammalian $\beta$-galactosidases that exhibit tolerance at the C-4 hydroxyl of the hexose moiety have been partially purified from rat kidney (3), pig kidney (4), bovine liver (5), and human liver (6). Separation of the activity exhibited toward glucosides and galactosides was not achieved by gel filtration (3-5), chromatography on DEAEcellulose $(3,6)$, or gel electrophoresis $(3)$; each activity was inhibited by gluconolactone and galactonolactone (3) or by C-4 epimers of the substrate glycosides (6). Pig intestinal mucosa was reported to contain an enzyme that exhibits similar nonspecificity for the hexose moiety (7). However, 
the intestinal enzyme was reported to hydrolyze lactose and may therefore be distinct from Type II $\beta$-galactosidase.

In this paper, we report the preparation and properties of a homogeneous aryl $\beta$ hexosidase from bovine liver which exhibits nonspecificity for the hydroxyl at C-4 (and possibly C-2) of arylhexosides. A preliminary report has been presented (8).

\section{MATERIALS AND METHODS}

$p$-Nitrophenyl $\beta\left[{ }^{3} \mathrm{H}\right] \mathrm{Gal}(9)$ and $N$-acetyllactosamine (1) were prepared as previously described. LSerine-O- $\beta$ Glc and $-\beta$ Gal were prepared by Koenigs-Knorr synthesis $(10,11)$. Escherichia coli $\beta$ galactosidase and galactose dehydrogenase were obtained from C.F. Boehringer Mannheim Corp., New York, N.Y.; salicin and esculin were purchased from Pfanstiehl Laboratories, Waukegan, Ill. Ficin $\alpha$-galactosidase was purified by the procedure of $\mathrm{Li}$ and $\mathrm{Li}$ (12). Molecular weight marker proteins were obtained from Schwarz/Mann Co., Orangeburg, N.J. Other chemicals were obtained from commercial sources and were of the highest grade available.

The following were generous gifts: phloridzin, Dr. L.H. Louis, University of Michigan; $\left[{ }^{4} \mathrm{C}\right]$ galactosyl $\mathrm{GM}_{1}$ ganglioside, Dr. S. Basu, University of Notre Dame; bovine nasal keratan sulfate, Dr. V. Hascall, National Institutes of Health; desialyzed orosomucoid, Dr. K. Schmid, Boston University; chonduritol B epoxide (3,5/4,6-cyclohex-1-ene-tetrol oxide), Dr. G. Legler, University of Cologne, Germany; $\left[{ }^{3} \mathrm{H}\right]$ lactosyl-, $\left[{ }^{3} \mathrm{H}\right]$ galactosyl-, and $\left[{ }^{3} \mathrm{H}\right]$ glucosyl-ceramides, Dr. N. Radin, University of Michigan; and $p$-NP- $\beta$-kojibiose, $-\beta$-cellobiose, $-\beta$-gentiobiose, $-\beta$ laminaribiose, and - $\beta$-sophorose, Dr. I.J. Goldstein, University of Michigan.

Paper electrophoresis was performed in a Model D high-voltage electrophorator (Gilson Medical Electronics, Middleton, Wisc.). Samples were streaked on Whatman $3 \mathrm{MM}$ paper saturated with $0.05 \mathrm{M}$ sodium tetraborate and subjected to $77 \mathrm{~V} / \mathrm{cm}$ for $60 \mathrm{~min}$. After drying the papers, uv-absorbing compounds were located by viewing with a Mineralight (Ultraviolet Products, San Gabriel, Calif.); radioactive compounds were located with a Packard radiochromatogram scanner. The radioactive areas of the paper were cut out and quantitated in a Packard liquid scintillation spectrometer as recommended by the manufacturer (Packard Instrument Co., LaGrange, Ill.).

\section{Enzyme Assay}

Unless otherwise indicated, reaction mixtures contained the following components in total volumes of $0.1 \mathrm{ml}$ : sodium phosphate-citrate buffer, $\mathrm{pH} 7.0$, as prepared by McIlvaine (13), $25 \mu \mathrm{l}$; bovine serum albumin, $100 \mu \mathrm{g} ; p$-NP $\beta \mathrm{Gal}, 5.0 \mu \mathrm{mol}$; and 3 to 10 units of enzyme. Control tubes contained the same components but lacked either substrate or enzyme. Incubations were conducted at $37^{\circ} \mathrm{C}$ for $10 \mathrm{~min}$ and were terminated by addition of $1 \mathrm{ml}$ of $0.25 \mathrm{M}$ glycine buffer, pH 10. Absorbance was measured at $400 \mathrm{~nm}$. A molar extinction coefficient of $1.75 \times 10^{4}$ was used to calculate the concentration of $p$-nitrophenol (1). A unit of enzyme was defined as that amount which released $1 \mathrm{nmol}$ of $p$-nitrophenol from $p$-NP $\beta \mathrm{Gal}$ in 1 min under the assay conditions described above. Protein was measured by the procedure of Lowry et al. (14).

When $p$-NP $\beta$ Glc was used as substrate, reactions were terminated by heating at $100^{\circ} \mathrm{C}$ for $1 \mathrm{~min}$. This procedure was necessary since the enzyme exhibited substantial activity with this substrate at $\mathrm{pH} 10$. After cooling, $1 \mathrm{ml}$ of glycine buffer, $\mathrm{pH} \mathrm{10,} \mathrm{was}$ added and the assay was performed as described above.

\section{Purification of Enzyme}

Preliminary fractionation. All steps were performed at 0 to $4^{\circ} \mathrm{C}$. Crude extracts of bovine liver were adjusted to $\mathrm{pH} 4$, stirred for $4 \mathrm{~h}$, and centrifuged at $10,000 \mathrm{~g}$, and a 20 to $75 \%$ ammonium sulfate fraction was obtained from the supernatant as previously reported (1). The ammonium sulfate fraction obtained from $220 \mathrm{~g}$ of liver was dissolved in $230 \mathrm{ml}$ of Mcllvaine buffer (13), $\mathrm{pH} \mathrm{4.3;700} \mathrm{ml}$ of water was added, and the solution was centrifuged at $10,000 \mathrm{~g}$ for $20 \mathrm{~min}$. To remove Type I $\beta$-galactosidase, the supernatant was passed through a $4 \times 13-\mathrm{cm}$ column of phenylthiogalactoside-substituted agarose (1) equilibrated with McIlvaine buffer, $\mathrm{pH} 4.3$ (diluted $1: 4, v / v$, with water). Arylhexosidase did not bind to the affinity column and was washed through the column with diluted buffer ( 1 column volume). Liver extracts required 10 times more substituted agarose than did testicular extracts to remove an equivalent amount of Type I $\beta$-galactosidase. This difference is presumably due to the higher initial protein concentration of liver. The liver preparation did not hydrolyze lactose after removal of Type I $\beta$-galactosidase by affinity chromatography. Prior to this step, approximately $5 \%$ of the hydrolytic activity (with $p$. NP $\beta \mathrm{Gal}$ as substrate and measured at $\mathrm{pH}$ 4.3) was due to the presence of Type I $\beta$-galactosidase $(1,2)$. The column effluent was adjusted to $\mathrm{pH} 7.5$ with 4.0 $\mathrm{N}$ sodium hydroxide and dialyzed for $24 \mathrm{~h}$ against 4 vol of $0.05 \mathrm{M}$ Tris- $\mathrm{HCl}, \mathrm{pH} 7.5 .^{3}$

\footnotetext{
${ }^{3}$ Recently, it was found that the affinity chromatography step was not essential for purification of this enzyme. In this modified procedure the ammonium sulfate fraction was dissolved in $0.05 \mathrm{M}$ Tris$\mathrm{HCl}, \mathrm{pH} 7.5$, dialyzed against the same buffer, and applied directly to DEAE-Sephadex as described
} 


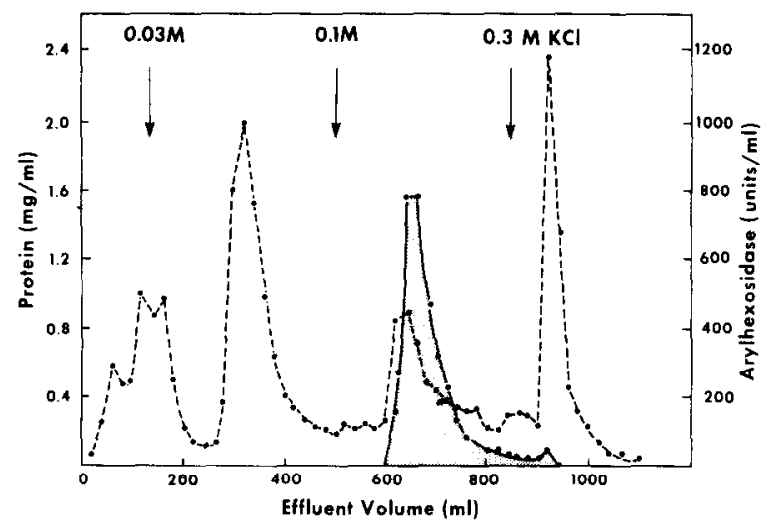

FIG. 1. Chromatography of aryl $\beta$-hexosidase on DEAE-Sephadex. Type I $\beta$-galactosidase was removed from an extract of bovine liver by passage through a column containing phenylthiogalactoside-substituted agarose as described in Materials and Methods. The effluent was dialyzed against $0.05 \mathrm{M}$ Tris- $\mathrm{HCl}, \mathrm{pH} 7.5$, and an aliquot $(100 \mathrm{ml})$ containing approximately 70,000 units of arylhexosidase was applied to a $2 \times 30-\mathrm{cm}$ column of DEAE-Sephadex A-50. The column was eluted sequentially with $0.05 \mathrm{M}$ Tris- $\mathrm{HCl}, \mathrm{pH} 7.5$, containing increasing amounts of potassium chloride. Fractions of $20 \mathrm{ml}$ were collected and protein (-----) and arylhexosidase (-) activity were determined as described in Materials and Methods.

Chromatography on DEAE-Sephadex. Dialyzed agarose effluent containing 70,000 units of arylhexosidase was applied to a $2 \times 30-\mathrm{cm}$ column of DEAESephadex (A-50) equilibrated with 0.05 M Tris- $\mathrm{HCl}$, $\mathrm{pH}$ 7.5. The column was eluted sequentially with $400-\mathrm{ml}$ volumes of $0.05 \mathrm{M}$ Tris- $\mathrm{HCl}, \mathrm{pH} 7.5$, containing potassium chloride at concentrations of 0.03 and $0.1 \mathrm{M}$, respectively. Fractions of $20 \mathrm{ml}$ were collected. Arylhexosidase activity eluted with $0.1 \mathrm{M}$ potassium chloride. Fractions containing enzyme activity were combined, adjusted to $\mathrm{pH} 5.0$ with $4 \mathrm{~N}$ acetic acid, and dialyzed for $24 \mathrm{~h}$ against 4 vol of 0.05 M sodium acetate buffer, $\mathrm{pH} 5.0$.

Fractionation with CM-Sephadex. The DEAESephadex eluant $(67,000$ units of arylhexosidase) was adjusted to $\mathrm{pH} 5.0$ and passed through a $2 \times 30$ $\mathrm{cm}$ column of CM-Sephadex (C-50) equilibrated with $0.05 \mathrm{~m}$ sodium acetate, $\mathrm{pH}$ 5.0. Arylhexosidase did not bind to the column and was washed through the column with 2 column volumes of acetate buffer. The effluents were combined and adjusted to $\mathrm{pH} 7.5$ with $1 \mathrm{M}$ Tris base, sodium chloride was added to a final concentration of $0.15 \mathrm{M}$, and the enzyme was concentrated by pressure filtration with nitrogen over an Amicon UM-10 membrane (Amicon Corp., Lexington, Mass.). The enzyme was stable indefinitely when stored at $-20^{\circ} \mathrm{C}$ in $30 \%$ glycerol; it could also be stored at $4^{\circ} \mathrm{C}$ for several months in the presence of $0.02 \%$ sodium azide without loss of activity.

above. Arylhexosidase prepared in this manner exhibited the same criteria of purity and substrate specificity as the enzyme preparation described in this report.

\section{RESULTS}

Arylhexosidase was purified to homogeneity by conventional enzyme fractionation procedures. Purification of the enzyme included chromatography on DEAESephadex (Fig. 1). This step promotes the separation of the enzyme from other acidic proteins. Subsequent passage through CM-Sephadex at $\mathrm{pH} 5.0$ removed less acidic proteins. The purification procedure yielded an 800-fold purified enzyme preparation (Table I) that catalyzed the cleavage $^{4}$ of $42 \mu \mathrm{mol}$ of $p$-NP $\beta \mathrm{Gal}$ per minute per milligram of protein.

Purified arylhexosidase gave single protein-staining bands on disc gel electrophoresis at $\mathrm{pH}$ values of 7.0 and 9.5 (Fig. 2). When duplicate unstained disc gel columns were sliced and eluted with buffers, the activity exhibited against $p$-NP- $\beta$ Gal and $-\beta$ Glc was found in the same fractions and migrated the same distance as the stained protein on disc gel columns.

Disc gel electrophoresis of the purified arylhexosidase in the presence of sodium

${ }^{4} \mathrm{~A}$ broad interpretation is given to the term "cleavage." In assays, where formation of nitrophenol is measured, cleavage may include transglycosylation. 
TABLE I

Purification of Arye $\beta$-Hexosidase from Bovine Liver ${ }^{a}$

\begin{tabular}{|c|c|c|c|c|c|}
\hline Procedure & $\underset{(\mathrm{ml})}{\text { Volume }}$ & $\begin{array}{l}\text { Total protein } \\
\text { (g) }\end{array}$ & $\begin{array}{c}\text { Total activ- } \\
\text { ity } \\
\text { (units } \times \\
10^{-3} \text { ) }\end{array}$ & $\begin{array}{c}\text { Specific activ- } \\
\text { ity } \\
\text { (units/mg) }\end{array}$ & $\begin{array}{l}\text { Recovery } \\
(\%)\end{array}$ \\
\hline Crude homogenate & 430 & 45.3 & 2,400 & 53 & 100 \\
\hline Supernatant & 430 & 22.5 & 2,030 & 90 & 85 \\
\hline Ammonium sulfate, $20-75 \%$ & 230 & 4.43 & 1,180 & 266 & 49 \\
\hline Negative affinity chromatography & 1,400 & 3.90 & 1,010 & 259 & 42 \\
\hline DEAE-Sephadex & 6,900 & 0.377 & 978 & 2,590 & 41 \\
\hline CM-Sephadex & $30^{\circ}$ & 0.022 & 950 & 42,400 & 40 \\
\hline
\end{tabular}

a Purification based on extraction of $220 \mathrm{~g}$ of bovine liver.

${ }^{b}$ Concentrated 400 -fold by pressure filtration.

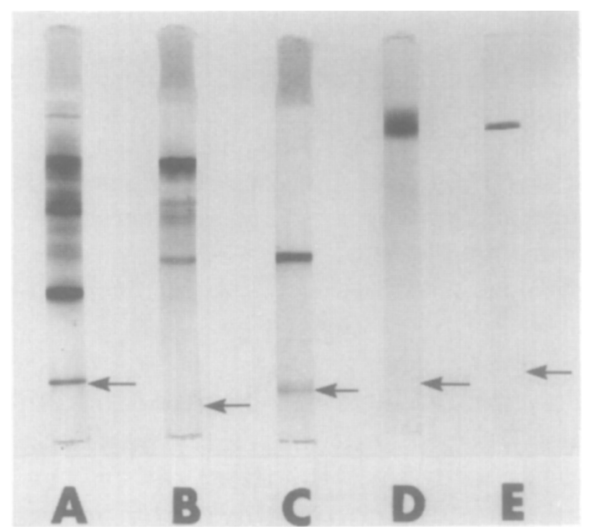

Fig. 2. Polyacrylamide gel electrophoresis of purified aryl $\beta$-hexosidase from bovine liver. Gel $A$ : pH 9.5, 7.0 units arylhexosidase (fraction after removal of Type I $\beta$-galactosidase by passage through phenylthiogalactoside-substituted agarose). Gel B: pH 9.5, 35 units arylhexosidase (DEAE-Sephadex). Gels C and D: pH 9.5 and 7.0, respectively, 712 units arylhexosidase (CM-Sephadex). Gel E: 475 units arylhexosidase (CM-Sephadex) was run in the presence of sodium dodecyl sulfate as described by Weber and Osborn (15). The gel columns buffered at $\mathrm{pH} 7.0$ and those run in the presence of sodium dodecyl sulfate were run without stacking gels. Gels were stained with Coomassie blue stain (15). Arrows indicate the position of the tracking dye.

dodecyl sulfate also yielded a single protein band (Fig. 2). Calibration of the distance of migration with authentic protein standards (15) gave an estimated molecular weight of 46,000 . Gel filtration of the purified enzyme on a calibrated column of Sephadex G-100 (16) yielded a single symmetrical peak which contained $\beta$-galactosidase and $\beta$-glucosidase activities; the apparent molecular weight was 41,000 .

\section{Specificity of Arylhexosidase}

The enzyme catalyzed the cleavage of $p$-NP $\beta$ Glc at $80 \%$ the rate of the corresponding Gal derivative. In addition to $p$ NP- $\beta \mathrm{Gal}$ and $-\beta \mathrm{Glc}$, the enzyme cleaved $p$ nitrophenyl derivatives of $\beta \mathrm{Man}, \beta \mathrm{Xyl}$, and $\alpha$ Ara, although at lower rates (Table II). The enzyme did not cleave $(<0.01 \%$ of the rate observed for $p$-NP $\beta \mathrm{Gal}$ ) the $p$ nitrophenyl derivatives of $\beta \mathrm{GlcNAc}$, $\beta$ GalNAc, $\beta$ GlcUA, $\alpha$ Man, $\beta$ Ara, $\alpha$ Glc, $\alpha \mathrm{Gal}$, or $\alpha \mathrm{Fuc}$. Nitrophenol was not released when $p$-NP- $\beta$-kojibiose or - $\beta$-gentiobiose served as substrate.

The enzyme catalyzed cleavage of several plant aryl $\beta$-glucosides, as shown in Table II. Esculin was cleaved at the same rate as $p$-NP $\beta \mathrm{Gal}$, salicin at 0.6 the rate, and phloridzin at 0.007 the rate. Phenyl $\beta$ Glc was cleaved approximately $10 \%$ faster than $p$-NP $\beta$ Gal.

Several nonaryl glycosides that contained terminal nonreducing $\beta$-hexosides were tested as potential substrates; no products were detected under conditions in which less than $0.01 \mathrm{nmol}$ per unit of enzyme per minute would have been detected. The glycosides tested included lactose, cellobiose, methyl- $\beta$ Glc and $-\beta \mathrm{Gal}$, desialyzed $\alpha_{1}$ acid glycoprotein, and keratan sulfate (Table II).

A reported deficiency of $\beta$-galactosidase, $\beta$-glucosidase, and $\beta$-xylosidase activities in liver from a patient with Gaucher's disease $(6,18)$ suggested the possibility that arylhexosidase was related to glucocerebrosidase, since the latter enzyme is deficient in Gaucher's disease (19). However, 
TABLE II

Substrate Specificity of Aryl $\beta$-Hexosidase from Bovine Liver ${ }^{a}$

\begin{tabular}{|c|c|c|c|c|}
\hline Experiment & Substrate & $\begin{array}{l}\text { Substrate concentra- } \\
\text { tion } \\
(\mathbf{m} \mathbf{M})\end{array}$ & $\underset{\text { (units) }}{\text { Enzyme }}$ & $\begin{array}{l}\text { Product formed } \\
\text { (nmol/min/unit) }\end{array}$ \\
\hline \multirow[t]{2}{*}{ I } & $p$-NP $\beta \mathrm{Gal}$ & 50 & 2 & 1.000 \\
\hline & $p$-NP $\beta \mathrm{Glc}$ & 50 & 2 & 0.840 \\
\hline \multirow[t]{6}{*}{ II } & $p$-NP $\beta \mathrm{Gal}$ & 5 & 2 & 0.682 \\
\hline & $p$-NP $\beta \mathrm{Glc}$ & 5 & 2 & 0.481 \\
\hline & $p$-NP $\beta \mathrm{Xyl}$ & 5 & 200 & 0.0103 \\
\hline & $p$-NP $\beta$ Man & 5 & 200 & 0.0036 \\
\hline & $p$-NP $\alpha$ Ara & 5 & 200 & 0.0026 \\
\hline & $\begin{array}{l}p \text {-NP- } \beta \text { GalNAc, }-\beta \mathrm{GlcNAc},-\alpha \text { Fuc, } \\
\text { - } \beta \text { GlcUA, }-\alpha \text { Man, }-\alpha \text { Glc, }-\beta \text { Ara, } \\
-\alpha \text { Gal, }-\beta \text {-kojibiose, and - } \beta \text {-gentio- } \\
\text { biose }\end{array}$ & 5 & 200 & $<0.0001$ \\
\hline \multirow[t]{5}{*}{ III } & Phenyl $\beta$ Glc & 5 & 2 & 1.140 \\
\hline & Esculin & 5 & 2 & 1.000 \\
\hline & Salicin & 5 & 2 & 0.619 \\
\hline & Phloridzin & 5 & 20 & 0.007 \\
\hline & $\begin{array}{l}\text { Methyl } \beta \text { Glc, cellobiose, and L-serine } \\
\beta \text { Glc }\end{array}$ & 50 & 200 & $<0.0001$ \\
\hline \multirow[t]{2}{*}{ IV } & $\begin{array}{l}\text { Lactose, L-serine } \beta \mathrm{Gal} \text {, and methyl } \\
\quad \beta \mathrm{Gal}\end{array}$ & 50 & 200 & $<0.0001$ \\
\hline & $\begin{array}{l}\text { Desialyzed } \alpha_{1} \text {-acid glycoprotein and bo- } \\
\text { vine nasal keratan sulfate }\end{array}$ & $(20 \mathrm{mg} / \mathrm{ml})$ & 200 & $<0.0001$ \\
\hline
\end{tabular}

a Reaction mixtures $(0.1 \mathrm{ml})$ contained $25 \mu \mathrm{l}$ of Mcllvaine buffer, $\mathrm{pH} 7.0 ; 100 \mu \mathrm{g}$ of bovine serum albumin; and the indicated amounts of arylhexosidase and substrates. Control reactions lacked enzyme. The mixtures were incubated at $37^{\circ} \mathrm{C}$ for $60 \mathrm{~min}\left(10 \mathrm{~min}\right.$ in Experiment I) and reactions terminated by heating at $100^{\circ} \mathrm{C}$ for $1 \mathrm{~min}$. The reaction products were determined by the following methods. Experiments I and II: $p$-Nitrophenol was measured as described in Materials and Methods. Experiment III: Reaction mixtures were placed on columns containing $100 \mu \mathrm{l}$ of Dowex-1, $\mathrm{HCO}_{3}{ }^{-}$resin (200-400 mesh) to remove phenols and the resin was washed with $0.9 \mathrm{ml}$ of water. The free glucose in the effluent was estimated with glucose oxidase (17). Experiment IV: Liberated galactose was estimated with galactose dehydrogenase (1). In Experiment II, the substrate concentration was reduced because of the limited solubility of some of the p-nitrophenyl derivatives.

in the present study no glucocerebrosidase activity (20) was detected in purified arylhexosidase preparations; nor did the enzyme cleave galactocerebroside (galactosyl ceramide) (21), lactocerebroside (lactosyl ceramide) (22), ${ }^{5}$ or $\mathrm{GM}_{1}$ ganglioside, labeled with ${ }^{14} \mathrm{C}$ in the galactose moiety. The latter reaction was assayed as previously reported (1) with the exception that the reaction was conducted at $\mathrm{pH} 7.0$ with 100 units of enzyme.

s These analyses were kindly performed by Dr. Norman Radin, University of Michigan. The limit of detection in each case was $1.6 \times 10^{-4} \mathrm{nmol} / \mathrm{min} / \mathrm{unit}$ of arylhexosidase.

\section{pH Optima for Arylhexosidase}

When $p$-NP $\beta \mathrm{Gal}$ or $p$-NP $\beta \mathrm{Glc}$ served as substrate, the enzyme exhibited a $\mathrm{pH}$ optimum of 7.0 in the presence of citratephosphate buffer (Fig. 3). In glycine buffer, the enzyme exhibited a second optimum at 9.0 for $\beta$-galactosidase activity and at $\mathrm{pH} 9.0$ to 9.5 for $\beta$-glucosidase activity. The rate of release of $p$-nitrophenol at $37^{\circ} \mathrm{C}$ was linear with respect to time for at least $6 \mathrm{~h}$ with each substrate and at each $\mathrm{pH}$ optimum. The $\beta$-galactosidase activity exhibited by arylhexosidase at $\mathrm{pH} 9.0$ was the same as that found at $\mathrm{pH} 7$. This property allowed accurate determination of ar- 


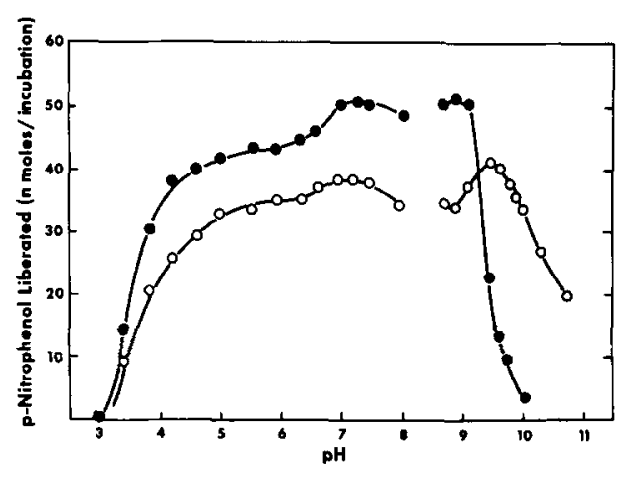

Fig. 3. Effect of $\mathrm{pH}$ on aryl $\beta$-hexosidase activity. The substrates were: $p$-NP $\beta \mathrm{Gal}, 0$; and $p$ NP $\beta$ Glc, $\Omega-O$. Mctlvaine buffer (13) was used in the $\mathrm{pH}$ range of 3 to 8 and $0.05 \mathrm{M}$ glycine-hydrochloride buffer in the range of 8.5 to 10.5 .

ylhexosidase at $\mathrm{pH} 9.0$ in tissue extracts containing large amounts of Type I (acid) $\beta$-galactosidase. Addition of glycine buffer at $\mathrm{pH} 10$ to reaction mixtures containing $p$ NP $\beta$ Glc did not stop enzymatic reactions; therefore, these incubations were terminated by heating at $100^{\circ} \mathrm{C}$ for $1 \mathrm{~min}$.

\section{Stimulation and Inhibition of Arylhexosi- dase Activity}

A variety of carbohydrates altered the rate of $p$-nitrophenol formation when $p$-NP $\beta$-glycosides served as substrates. As shown in Table III, addition of methyl$\alpha$ Glc or $-\alpha \mathrm{Gal}$ to reaction mixtures resulted in a 35 to $80 \%$ increase in the rate of release of $p$-nitrophenol. Stimulation of nitrophenol production by some carbohydrates depended upon whether $p-\mathrm{NP}-\beta \mathrm{Gal}$ or $-\beta$ Glc served as substrate. Addition of phloridzin, galactal, and methyl $\alpha$ Man resulted in an increased rate of nitrophenol release in reaction mixtures in which $p$ NP $\beta$ Gal served as substrate, but not when $p$-NP $\beta$ Glc served as substrate. The extent of inhibition by some carbohydrates was also dependent upon the substrate utilized. Thus, methyl $\beta \mathrm{Gal}$ reduced nitrophenol production by about $50 \%$ from $p$-NP $\beta \mathrm{Gal}$ but did not significantly alter nitrophenol production from $p$-NP $\beta$ Glc. The effect of each carbohydrate on the enzymatic reaction may be due to a combination of factors, including inhibition and stimulation due to transglycosylation re- actions as described below. It is of interest that while methyl $\beta \mathrm{Gal}$ and $\beta \mathrm{Glc}$ are not detectably cleaved by arylhexosidase (Table II), these compounds were potent inhibitors (Table III).

Differences in the extent of inhibition or stimulation of $\beta$-galactosidase and $\beta$-glucosidase activities suggested that separate enzymes might be present for the hydrolysis of each type of glycoside. However, when aryl hexosidase was treated with the specific glucosidase inhibitor, chonduritol $B$ epoxide (23), $\beta$-galactosidase, and $\beta$-glucosidase activities were reduced by the same relative amount (Fig. 4). These results suggest that aryl $\beta$-galactosides and aryl $\beta$-glucosides are cleaved at the same catalytic site. As expected, bovine testicular $\beta$-galactosidase, which does not hydrolyze $\beta$-glucosides (1), was not inhibited by chonduritol B epoxide (Fig. 4).

\section{Transglycosylation Activity of Arylhexosi- dase}

When reaction mixtures containing $p$ NP $\beta\left[{ }^{3} \mathrm{H}\right] \mathrm{Gal}$ and arylhexosidase were subjected to paper electrophoresis, a ${ }^{3} \mathrm{H}$ labeled uv-absorbing compound which mi-

TABLE III

Stimulation and Inhibition of Aryl $\beta$ HeXosidase by Carbohydrates ${ }^{a}$

\begin{tabular}{lcc}
\hline \multicolumn{1}{c}{ Addition } & \multicolumn{2}{c}{ Substrate } \\
\cline { 2 - 3 } & $\begin{array}{l}p \text {-NP } \beta \text {-Galactoside } \\
\text { (nmol/min/unit of }\end{array}$ \\
\hline None & 0.63 & 0.48 \\
Methyl $\alpha \mathrm{G}$ & 1.14 & 0.65 \\
Methyl $\alpha \mathrm{Gal}$ & 1.03 & 0.77 \\
Methyl $\alpha \mathrm{Man}$ & 0.83 & 0.49 \\
Methyl $\alpha \mathrm{Xyl}$ & 0.70 & 0.46 \\
Galactal & 0.86 & 0.47 \\
Phloridzin & 0.82 & 0.41 \\
Lactose & 0.62 & 0.44 \\
Maltose & 0.62 & 0.42 \\
Galactose & 0.61 & 0.44 \\
Glucose & 0.53 & 0.40 \\
Methyl $\beta \mathrm{Gal}$ & 0.32 & 0.44 \\
Methyl $\beta \mathrm{Xyl}$ & 0.19 & 0.28 \\
Methyl $\beta \mathrm{Glc}$ & 0.14 & 0.29 \\
\hline
\end{tabular}

${ }^{a}$ Incubation and assay conditions were those described in Materials and Methods except that each reaction mixture contained $0.5 \mu \mathrm{mol}$ of $p$-nitrophenyl glycoside as substrate and $15 \mu \mathrm{mol}$ of added carbohydrate $(0.3 \mu \mathrm{mol}$ of phloridzin). 


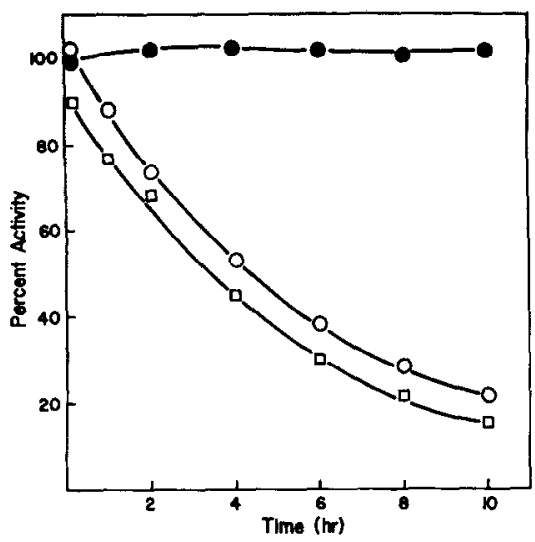

FIG. 4. Inhibition of arylhexosidase by chonduritol B epoxide. Arylhexosidase (137 units) or type I $\beta$ galactosidase (94 units) was preincubated at $37^{\circ} \mathrm{C}$ in reaction mixtures $(0.2 \mathrm{ml})$ containing $10 \mu \mathrm{mol}$ of sodium acetate, $\mathrm{pH} 5.8 ; 1.0 \mu \mathrm{mol}$ of chonduritol $\mathrm{B}$ epoxide; and $0.2 \mathrm{mg}$ of bovine albumin. At the indicated times, aliquots of the solutions were removed and assayed for enzymatic activity [arylhexosidase, using $p$-NP $\beta$ Gal $(O-O)$ and $p$-NP $\beta$ Gle $(\square-\square)$ as substrates or Type I $\beta$-galactosidase (-)]. Control incubations lacked chonduritol B epoxide. The values presented are percentages of enzymatic activity in control mixtures where $p$-NP $\beta$ Gal served as substrate.

grated more rapidly than $p$-NP $\beta\left[{ }^{3} \mathrm{H}\right] \mathrm{Gal}$ was detected in addition to the expected products: $\left[{ }^{3} \mathrm{H}\right]$ galactose, $p$-nitrophenol, and residual $p$-NP $\beta\left[{ }^{3} \mathrm{H}\right] \mathrm{Gal}$ (Scan A, Fig. 5). The uv-absorbing compound was eluted from electrophoretograms and, when incubated with $E$. coli $\beta$-galactosidase, yielded $\left[{ }^{3} \mathrm{H}\right]$ galactose and $p$-nitrophenol in a ratio of 2.0:1.0. The unidentified compound was not cleaved when incubated with purified arylhexosidase or ficin $\alpha$-galactosidase and is presumed to be $p-\mathrm{NP} \beta\left[{ }^{3} \mathrm{H}\right] \mathrm{Gal}-$ $\beta\left[{ }^{3} \mathrm{H}\right] \mathrm{Gal}$. The formation of the latter compound in reaction mixtures containing arylhexosidase indicates that $p$-NP $\beta\left[{ }^{3} \mathrm{H}\right] \mathrm{Gal}$ acts both as a glycosyl donor and as a glycosyl acceptor.

Paper chromatography of reaction mixtures that contained $p$-NP $\beta$ Glc as substrate revealed the presence of a "new" compound that cochromatographed with $p$ NP $\beta$ Glc- $(\beta 1,6)$-Glc (Fig. 6). A single "new" uv-absorbing ${ }^{3} \mathrm{H}$-labeled compound was also obtained when reaction mixtures contained $p$-NP $\beta\left[{ }^{3} \mathrm{H}\right] \mathrm{Gal}$ as substrate. Po- sition isomers of $p$-NP disaccharides containing galactose were not available for these studies.

Arylhexosidase also catalyzed transglycosylation of $\left[{ }^{3} \mathrm{H}\right]$ galactosyl residues from $p$-NP $\beta\left[{ }^{3} \mathrm{H}\right]$ Gal to methyl $\alpha$ Glc to form a glycoside which remained near the origin of electrophoretograms (Scan B, Fig. 5). Treatment of this glycoside with $E$. coli $\beta$ galactosidase yielded $\left[{ }^{3} \mathrm{H}\right]$ galactose. The compound is presumed to be methyl $\alpha \mathrm{Glc}$ $\beta\left[{ }^{3} \mathrm{H}\right] \mathrm{Gal}$. Glycosides were also formed in reaction mixtures that contained other

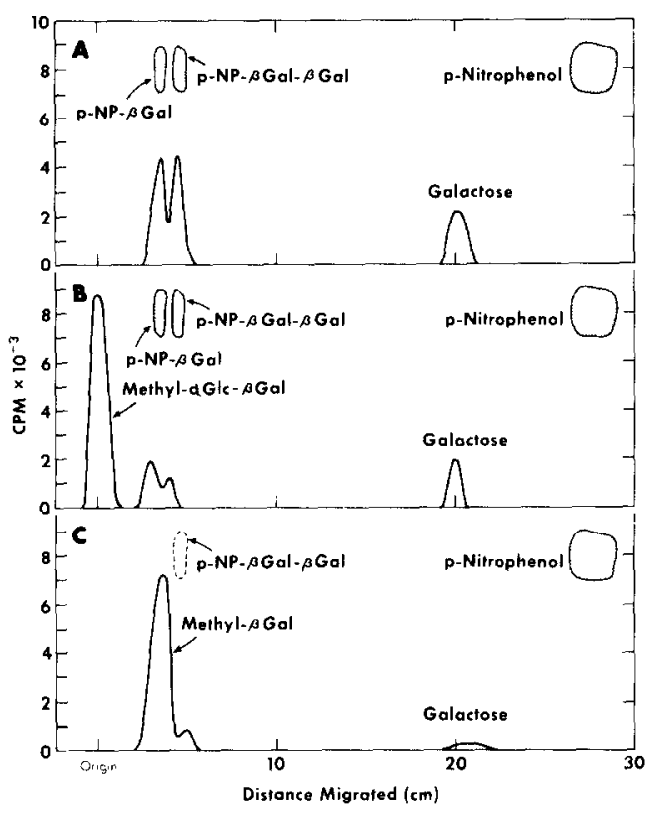

FIG. 5. Paper electrophoresis of $\left[{ }^{3} \mathrm{H}\right.$ Jgalactosides formed by aryl $\beta$-hexosidase. Standard reaction mixtures $(0.1 \mathrm{ml})$ contained $p$-NP $\beta\left[{ }^{3} \mathrm{H}\right] \mathrm{Gal}(4.5 \times$ $10^{\mathrm{s}} \mathrm{cpm}$ ), $25 \mu \mathrm{l}$ of McIlvaine buffer, $10 \mu \mathrm{g}$ of bovine serum albumin, and 50 units of arylhexosidase. After incubation at $37^{\circ} \mathrm{C}$ for the times indicated below, aliquots were subjected to paper electrophoresis in $0.05 \mathrm{M}$ sodium tetraborate as described in Materials and Methods. Scan A: The mixture contained no additions and was incubated for $1 \mathrm{~h}$. Scan B: The mixture contained $30 \mu \mathrm{mol}$ of methyl $\alpha \mathrm{Glc}$ and was incubated for $1 \mathrm{~h}$. Scan C: The mixture contained $5 \%$ methanol and was incubated for $5 \mathrm{~h}$ until $p$-NP $\beta\left[{ }^{3} \mathrm{H}\right] \mathrm{Gal}$ was depleted. Identification of $p$-NP $\beta\left[{ }^{3} \mathrm{H}\right] \mathrm{Gal}-\beta\left[{ }^{3} \mathrm{H}\right] \mathrm{Gal}$, methyl $\alpha \mathrm{Glc}-\beta\left[{ }^{3} \mathrm{H}\right] \mathrm{Gal}$ and methyl $\beta\left[{ }^{3} \mathrm{H}\right] \mathrm{Gal}$ is discussed in the text; other compounds were identified by electrophoresis with authentic standards. The shaded areas indicate the positions of uv-absorbing compounds. 

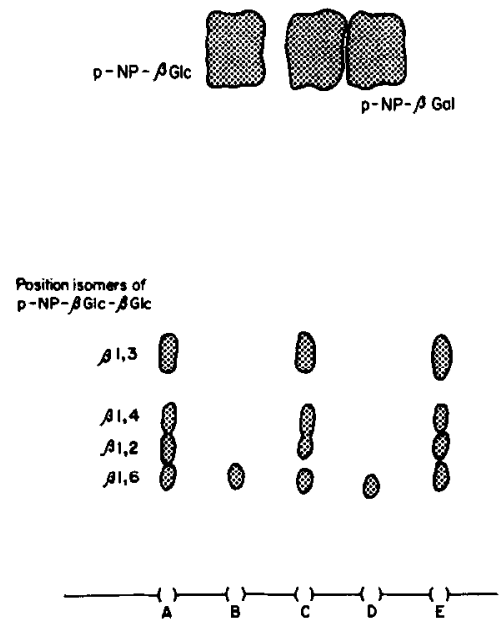

Fig. 6. Chromatography of $p$-NP disaccharides. Whatman No. 1 paper chromatograms were irrigated in a descending fashion for $6 \mathrm{~h}$ with a 2butanone-water (22:3 by weight) mixture. $A$ and $\mathbf{E}$ are a mixture of authentic position isomers of $p-\mathrm{NP}$ $\beta$ Glc- $\beta$ Glc containing $0.4 \mu \mathrm{mol}$ each of $p$-NP $\beta$-gentiobiose $(\beta 1,6), p$-NP $\beta$-cellobiose $(\beta 1,4), p$-NP $\beta$ laminaribiose $(\beta 1,3)$, and $p$-NP $\beta$-sophorose $(\beta 1,2)$; $\mathrm{B}, 25 \mu \mathrm{l}$ of a reaction mixture described in Materials and Methods containing 50 units of arylhexosidase and $p$-NP $\beta$ Glc as substrate; $\mathrm{C}$, a mixture of components of $A$ and $B$; and $D, 25 \mu$ of a reaction mixture described in Materials and Methods containing 50 units of arylhexosidase and $p$-NP $\beta \mathrm{Gal}$ as substrate. The components were visualized by ultraviolet absorption.

methyl glycosides as glycosyl acceptors (Table IV). A ratio of newly synthesized, ${ }^{3} \mathrm{H}$-labeled glycosides to free $\left[{ }^{3} \mathrm{H}\right]$ galactose of about 4:1 was obtained in reaction mixtures containing methyl $\alpha$ Glc as acceptor.

Ethyl and methyl alcohols served as acceptors for galactosyl residues. When either ethyl or methyl alcohol was added to reaction mixtures in a final concentration of $0.03 \mathrm{M}$, analysis of the reaction products revealed a ratio of "new" glycoside to free galactose of approximately 4.5:1 (Table IV). At higher cencentrations of methyl alcohol $(5 \%, 1.2 \mathrm{M})$, the ratio of methyl $\beta\left[{ }^{3} \mathrm{H}\right] \mathrm{Gal}$ to $\left[{ }^{3} \mathrm{H}\right]$ galactose approximated 25:1 (Scan C, Fig. 5). The glycoside synthesized when methyl alcohol served as acceptor was identified as methyl $\beta \mathrm{Gal}$ by recrystallization of the compound $(3.4 \times$ $10^{5} \mathrm{cpm}$ ) in the presence of $20 \mathrm{mg}$ of au- thentic methyl $\beta \mathrm{Gal}$ to a constant specific activity $(2500 \mathrm{cpm} / \mu \mathrm{mol}$ of galactose).

The ability of $\alpha$-linked glycosides to accept galactose residues when incubated with arylhexosidase and $p$-NP $\beta\left[{ }^{3} \mathrm{H}\right] \mathrm{Gal}$ and our previous demonstration that bovine testicular $\beta$-galactosidase catalyzes formation of UDP-disaccharides (9) prompted us to test the ability of arylhexosidase to transfer galactose residues to $\alpha$ linked UDP-Glc and UDP-GlcNAc; no UDP-disaccharide formation was detected (Table IV).

\section{Effect of Substrate Concentration}

The ability of $p$-NP $\beta$ Gal to participate both as a substrate (glycosyl donor) and an

TABLE IV

Formation of Transglycosylation Products by ARYL $\beta$-HEXosidase ${ }^{\alpha}$

\begin{tabular}{|c|c|c|c|c|}
\hline Acceptor & $\begin{array}{l}\text { "New" } \\
\text { glyco- } \\
\text { side } \\
\text { formed } \\
(\text { cpm } \times \\
\left.10^{-3}\right)\end{array}$ & $\begin{array}{c}p \text {-NP } \\
\beta\left[{ }^{3} \mathrm{H}\right] \mathrm{Gal}- \\
\beta\left[{ }^{3} \mathrm{H}\right] \mathrm{Gal} \\
\text { formed } \\
\left(\mathrm{cpm} \times 10^{-3} \text { ) }\right.\end{array}$ & $\begin{array}{c}\text { Galac- } \\
\text { tose } \\
\text { formed } \\
(\mathrm{cpm} \times \\
\left.10^{-3}\right)\end{array}$ & $\begin{array}{l}\text { cpm of } \\
\text { "new" } \\
\text { glyco- } \\
\text { side per } \\
\text { cpm of } \\
\text { galac- } \\
\text { tose }\end{array}$ \\
\hline None & - & 134 & 173 & - \\
\hline Ethyl alcohol & 270 & 28 & 58 & 4.66 \\
\hline Methyl alcohol & $318^{b}$ & 34 & 72 & 4.42 \\
\hline Methyl $\alpha$ Glc & 317 & 10 & 79 & 4.01 \\
\hline Methyl $\alpha \mathrm{Gal}$ & $300^{b}$ & 33 & 106 & 2.83 \\
\hline Phloridzin & 108 & 78 & 140 & 0.77 \\
\hline Methyl $\beta \mathrm{Glc}$ & 48 & 80 & 64 & 0.75 \\
\hline Methyl $\beta \mathrm{Gal}$ & 5 & 111 & 125 & 0.04 \\
\hline UDP-Glc & $0^{c}$ & 92 & 149 & 0.00 \\
\hline UDP-GIcNAc & $0^{c}$ & 104 & 135 & 0.00 \\
\hline
\end{tabular}

${ }^{a}$ Reaction mixtures $(0.1 \mathrm{ml})$ contained $p$-NP $\beta\left[{ }^{3} \mathrm{H}\right] \mathrm{Gal}\left(4.5 \times 10^{5} \mathrm{cpm}\right) ; 30 \mu \mathrm{mol}$ of acceptor compound (except $0.3 \mu \mathrm{mol}$ of phloridzin); $25 \mu \mathrm{l}$ of McIlvaine buffer, $\mathrm{pH} 7.0 ; 10 \mu \mathrm{g}$ of serum albumin; and 50 units of purified arylhexosidase. The mixtures were incubated at $37^{\circ} \mathrm{C}$ for $1 \mathrm{~h}$ and the ${ }^{3} \mathrm{H}$-labeled products were determined as described in the legend to Fig. 5. The results are presented as $10^{-3} \mathrm{cpm}$ of product per reaction mixture.

${ }^{b}$ The reaction mixtures that contained methyl $\alpha \mathrm{Gal}$ or methyl alcohol as acceptor were incubated for $5 \mathrm{~h}$ to deplete $p$-NP $\beta\left[{ }^{3} \mathrm{H}\right] \mathrm{Gal}$; the latter compound migrated nearly the same distance as the "new" glycosides formed in these reaction mixtures.

${ }^{c}$ Migration of the hypothetical UDP-disaccharide on paper electrophoretograms was assumed to be the same as that found for UDP-disaccharides formed by Type I $\beta$-galactosidase (9). 


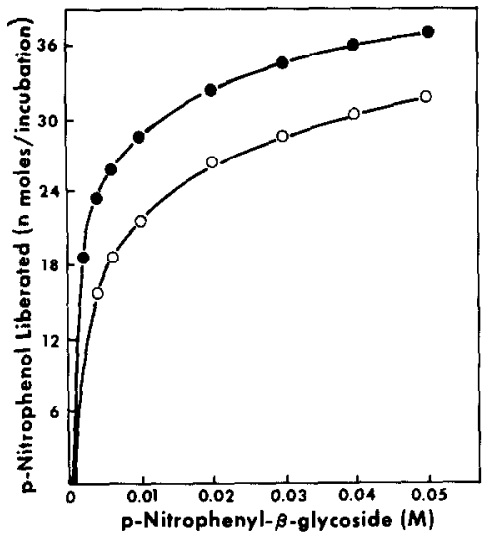

FIG. 7. Effect of substrate concentration on aryl $\beta$-hexosidase activity. Assay of enzyme activity was performed as described in Materials and Methods except that the concentration of substrate was varied; - $p$-NP $\beta$ Gal; O-O, $p$-NP $\beta$ Glc. Reaction mixtures contained 6.0 units of purified arylhexosidase.

acceptor of glycosyl residues complicated substrate kinetic studies. It is clear that the presence of acceptor molecules can increase the rate of enzymatic reaction and lead to inaccurate values for enzyme activity and substrate requirements. Preliminary attempts to saturate the enzyme with $p$-NP- $\beta$ Gal or $-\beta$ Glc indicated that very high substrate concentrations were required (Fig. 7). Measurements of enzyme activity were therefore performed at the highest practical substrate concentrations $(0.05 \mathrm{M})$.

When the rate of formation of $p$-nitrophenol from $p$-NP $\beta$ Gal was plotted by the method of Lineweaver and Burk, an apparent $K_{m}$ for $p$-NP $\beta$ Gal of $8.5 \times 10^{-3} \mathrm{M}$ was obtained (Fig. 8). However, when the glycosyl acceptor, methyl $\alpha \mathrm{Glc}$, was added to reaction mixtures to a concentration of $0.15 \mathrm{M}$, the $K_{m}$ obtained for $p$-NP $\beta$ Gal was lower $\left(1.78 \times 10^{-3} \mathrm{M}\right)$. This latter value should more closely approximate the affinity of the enzyme for the glycosyl donor since a relatively high concentration of acceptor was provided for the reaction. The $K_{m}$ obtained for $p$-NP $\beta$ Glc was $2.50 \times 10^{-3}$ $M$ in the presence of $0.15 \mathrm{M}$ methyl $\alpha$ Glc.

Kinetic studies performed in the presence of methyl $\beta \mathrm{Glc}$ indicated that this compound was a competitive inhibitor of arylhexosidase (Fig. 8).

\section{Species Distribution of Arylhexosidase}

Advantage was taken of the observation that the enzyme readily cleaved $p$-NP $\beta \mathrm{Gal}$ at $\mathrm{pH} 9.0$ to directly estimate the level of arylhexosidase in crude liver homogenates from several animals (Table $V)$. The richest sources of the enzyme were bovine and porcine liver; lower levels of enzyme were found in liver homogenates of other mammals and in the frog. All mammalian livers tested contained arylhexosidase in variable amounts. In general, the specific activity of arylhexosidase in the liver of mammals was directly related to the size of the animal. No arylhexosidase $(<0.01$ units/mg of protein) was detected in the livers or kidneys obtained from birds, fish, or reptiles (Table V).

\section{Tissue and Intracellular Distribution of Arylhexosidase}

Several bovine tissues were surveyed for arylhexosidase activity. The enzyme was found in liver, kidney, and intestine but not in spleen, skeletal muscle, serum, or testis (Table V). When bovine liver was homogenized in $0.25 \mathrm{M}$ sucrose and fractionated by the procedure of Schachter et $a l$. (25), more than $90 \%$ of the enzyme was found in the cytosol (Table VI).

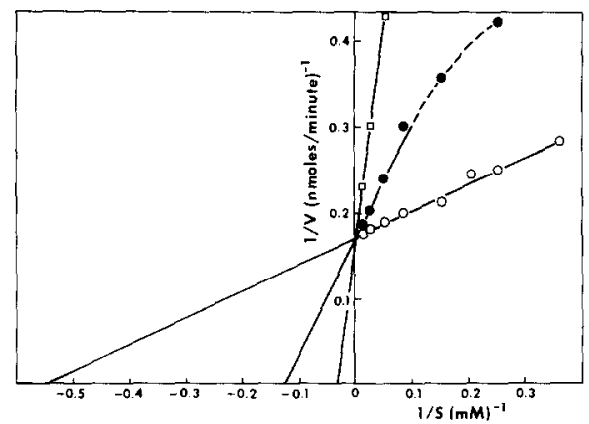

Fig. 8. Lineweaver-Burk plots for $p$-NP $\beta \mathrm{Gal}$. Initial reaction rates were determined as described in Materials and Methods. Reaction mixtures contained $p$-NP $\beta$ Gal and 6.0 units of purified arylhexosidase; - no additions; $\mathrm{O}-\mathrm{O}$, in the presence of $0.15 \mathrm{M}$ methyl $\alpha \mathrm{Glc}$; and $\square-\square$, in the presence of $0.15 \mathrm{M}$ methyl $\beta$ Glc. 
Less than $1 \%$ of the arylhexosidase was detected in the lysosome fraction where Type I $\beta$-galactosidase was concentrated; testis and spleen which contained Type I $\beta$-galactosidase had no detectable arylhexosidase, suggesting that the distributions of these two enzymes were not related.

\section{TABLE V}

Distribution of ARYL $\beta$-HeXosidase IN Vertebrate Tissues ${ }^{a}$

\begin{tabular}{|c|c|c|}
\hline Tissue & $\begin{array}{l}\text { Arylhexosid } \\
\text { (nmol of pro }\end{array}$ & $\begin{array}{l}\text { I } \beta \text {-galacto- } \\
\text { sidase } \\
\alpha / \mathrm{mg} \text { of pro- }\end{array}$ \\
\hline \multicolumn{3}{|l|}{ Mammal } \\
\hline Liver (bovine) & 39.0 & 0.06 \\
\hline Kidney (bovine) & 1.69 & 0.28 \\
\hline $\begin{array}{r}\text { Small intestine } \\
\text { (calf, mucosa) }\end{array}$ & 0.22 & ND \\
\hline Spleen (bovine) & $<0.01$ & 0.15 \\
\hline Muscle (bovine) & $<0.01$ & $<0.01$ \\
\hline Serum (bovine) & $<0.01$ & $<0.01$ \\
\hline Testis (bovine) & $<0.01$ & 1.20 \\
\hline Liver (porcine) & 24.2 & 0.46 \\
\hline Liver (human) & 15.3 & 0.16 \\
\hline Liver (guinea pig) & 6.49 & 0.59 \\
\hline Liver (rabbit) & 6.32 & 0.33 \\
\hline Liver (rat) & 0.88 & 0.29 \\
\hline Liver (beaver) & 0.83 & 0.16 \\
\hline Liver (mouse) & 0.20 & 0.29 \\
\hline \multicolumn{3}{|l|}{ Amphibian } \\
\hline $\begin{array}{l}\text { Liver (frog, Rana } \\
\text { pipiens) }\end{array}$ & 0.75 & 0.28 \\
\hline $\begin{array}{l}\text { Kidney (frog, Rana } \\
\text { pipiens) }\end{array}$ & 0.73 & 1.30 \\
\hline $\begin{array}{l}\text { Reptiles, birds, and } \\
\text { fish }^{c}\end{array}$ & $<0.01$ & $<0.01$ \\
\hline
\end{tabular}

${ }^{a}$ Each tissue was homogenized in $4 \mathrm{vol}$ of $\mathrm{Mc}$ Ilvaine buffer, $\mathrm{pH} 7.0$ and centrifuged at $2000 \mathrm{~g}$ to remove whole cells and debris. Estimation of arylhexosidase was performed as described under Enzyme Assay in Materials and Methods, except that $0.2 \mathrm{M}$ glycine-hydrochloride buffer, $\mathrm{pH} \mathrm{9.0,} \mathrm{replaced}$ the citrate-phosphate buffer. Type I $\beta$-galactosidase was determined as previously described with lactose as substrate (1). In some cases, incubation time was increased to $6 \mathrm{~h}$.

${ }^{b}$ Not determined because of the presence of intestinal lactase (24).

c Liver and kidney homogenates of the following species lacked arylhexosidase activity $(<0.01 \mathrm{nmol}$ of $p$-nitrophenol formed per minute per milligram of protein): chicken, quail (Colinis virginianus), trout (Salmo trutta), and turtles (Chelydra serpentina and Chrysemys picta).
TABLE VI

Intracellular Localization of Bovine Aryl $\beta$ HeXosidase ${ }^{a}$

\begin{tabular}{lrcc}
\hline \multicolumn{1}{c}{ Fraction } & $\begin{array}{c}\text { Total } \\
\text { activity } \\
\text { (units) }\end{array}$ & $\begin{array}{c}\text { Protein } \\
\text { (mg) }\end{array}$ & $\begin{array}{c}\text { Specific } \\
\text { activity } \\
\text { (units/mg of } \\
\text { protein) }\end{array}$ \\
\hline $\begin{array}{l}\text { Nuclei } \\
\begin{array}{l}\text { Mitochondria and } \\
\text { lysosomes }\end{array}\end{array}$ & 44 & 52 & 0.8 \\
$\begin{array}{l}\text { Supernatant over } \\
\text { mitochondria }\end{array}$ & 700 & 173 & 4.0 \\
$\begin{array}{l}\text { and lysosome } \\
\text { pellet }\end{array}$ & & & \\
$\begin{array}{l}\text { Microsomes } \\
\text { Cytosol }\end{array}$ & 365 & 52 & 7.0 \\
& 12,500 & 126 & 99.2 \\
Crude extract & 13,200 & 500 & 26.4 \\
\hline
\end{tabular}

a Fresh bovine liver $(3.0 \mathrm{~g})$ was homogenized in a sucrose-salts buffor and subjected to differential centrifugation as described by Schachter et al. (25), Fractions were assayed for arylhexosidase at $\mathrm{pH} 9.0$ as described in Table $\mathrm{V}$.

${ }^{b}$ Low amounts of Type I $\beta$-galactosidase were found in bovine liver (Table V). After differential centrifugation, it was detectable only in the mitochondrial-lysosome fraction.

\section{DISCUSSION}

A glycosidase that catalyzes the hydrolysis of a variety of aryl $\beta$-D-glucosides and of $p$-NP- $\beta \mathrm{Gal},-\beta \mathrm{Man},-\beta \mathrm{Xyl}$, and $\alpha$ Ara was purified to homogeneity from bovine liver. The name aryl $\beta$-hexosidase is proposed for the enzyme to describe properly the requirement for the aryl aglycone portion of its substrate and the nonspecificity exhibited toward the hexose moiety of the substrate glycosides. A number of nonaryl glycosides were tested as substrates. These included disaccharides, glycoproteins, serine and methyl $O$-glycosides, glycolipids, and $p$-NP disaccharides. None of these compounds served as substrates for arylhexosidase $(<0.01 \%$ of the rate with $p$-NP $\beta$ Gal).

Enzymes in mammalian liver and kidney extracts having properties similar to those of arylhexosidase have been described by others and variously termed "neutral" $\beta$-galactosidase (26), Type II $\beta$ galactosidase $(1,5), \beta$-xylosidase $(27), \beta$ glucosidase $(28,29)$, and steroid $\beta$-glucosidase $(8,30)$. Evidence that these enzyme 
activities are similar to arylhexosidase is based on the following criteria: distribution limited to liver, kidney, and intestine of mammals; presence in the cytosol fraction; molecular weight of $40,000-46,000$; and activity on both aryl $\beta$-glucosides and $\beta$-galactosides. The term "neutral" $\beta$-galactosidase is not appropriate for the presently described enzyme since it exhibits at least two $\mathrm{pH}$ optima in the range 9.0 to 9.5 . Further, the term "neutral" $\beta$-galactosidase has been applied to a separate enzymecatalyzing lactose hydrolysis $(31,32)$. The name $\beta$-glucosidase [ $\beta$-D-glucoside: glucohydrolase (EC 3.2.1.21)] is frequently applied to arylhexosidase-like enzymes, perhaps in part due to the similar tolerance for the position of the hydroxyl at C-4 exhibited by almond emulsin $\beta$-glucosidase and intestinal disaccharidase (33), and in part to the higher levels of $\beta$-glucosidase activity observed in some preparations of these enzymes. Thus, while arylhexosidase-like enzymes from bovine liver $(1,5)$, pig kidney (28), and human liver (34) appear to favor hydrolysis of $\beta$-galactosides over $\beta$-glucosides, enzymes obtained from rat kidney are reported to hydrolyze $\beta$ glucosides at about four times the rate of $\beta$-galactosides $(28,29)$.

All attempts to separate the $\beta$-glucosidase and $\beta$-galactosidase activities of arylhexosidase by conventional fractionation procedures were unsuccessful, indicating that these two activities may reside on the same or very similar enzyme molecules. However, evidence was obtained suggesting that the two catalytic activities may be distinct, i.e., the relative rates of hydrolysis of $p$-NP $\beta \mathrm{Gal}$ and $p$-NP $\beta \mathrm{Glc}$ differed at alkaline $\mathrm{pH}$ values (Fig. 3), and differences were observed in the stimulation and/or inhibition of these two enzyme activities in the presence of added carbohydrates (Table III). The hypothesis that separates sites are involved for $\beta$-galactosidase and $\beta$-glucosidase activities of arylhexosidase is, however, challenged by the observation that the specific glucosidase inhibitor, chonduritol B epoxide, inactivates the $\beta$-galactosidase and $\beta$-glucosidase activites at nearly the same rate (Fig. 4). Only $\beta$-galactosidases that ex- hibit tolerance for the position of the hydroxyl group at C-4 are reported to be inhibited by chonduritol B epoxide (23). Testicular $\beta$-galactosidase, which has no demonstrable $\beta$-glucosidase activity (1), is not inactivated by chonduritol $\mathrm{B}$ epoxide.

The ability of arylhexosidase to catalyze transglycosylation reactions complicated kinetic studies. The enzyme was not saturated even at high concentrations of substrate aryl glycosides (Fig. 7). Recognition that aryl glycosides participated not only as glycosyl donors but also as acceptors for glycosyl residues prompted inclusion of alternate acceptor compounds such as methyl $\alpha$ Glc in incubation mixtures. $\mathrm{Ki}$ netic measurements could then be performed on substrate aryl glycosides without their participation as acceptor compounds. In kinetic studies performed in the presence of $0.15 \mathrm{M}$ methyl $\alpha$ Glc: (i) no inhibition of glycosidase activity could be detected (Table III); (ii) arylhexosidase showed conventional saturation kinetics (Fig. 8); (iii) little transfer of glycosyl residues to the substrate aryl glycoside was detected (Table IV); and (iv) the $K_{m}$ value for $p$-NP $\beta \mathrm{Gal}$ was five times lower than the apparent value observed in the absence of methyl $\alpha$ Glc (Fig. 8).

Attempts to measure the levels of arylhexosidase-like enzymes in different animals and tissues were complicated by the presence of lysosomal acid glycosidases which exhibited considerable activity even at $\mathrm{pH} 7.0$ (1). In the present study, it was demonstrated that arylhexosidase can be measured specifically by a sensitive assay procedure utilizing the alkaline $\mathrm{pH}$ optimum of the enzyme. The specificity of the method was indicated by the demonstrated absence of arylhexosidase in bovine testis, a tissue which contains high levels of acid glycosidases. The sensitivity of the method was demonstrated by measurement of arylhexosidase-like activity in rat liver, where conventional methods had suggested that it was absent (5).

While arylhexosidase comprises a relatively large fraction of the protein contained in the cytosol of bovine liver $(>0.2 \%)$, the biological role of the enzyme is unclear. The ability of arylhexosidase to 
catalyze transfer of glycosyl residues efficiently, the possible presence of specific acceptor-binding sites on the enzyme, and the specific formation of 6-substituted sugars suggest a potential "synthetic" role for arylhexosidase. However, preliminary experiments have not supported this hypothesis. The purified enzyme does not form glycogen or lactose when incubated in the presence of the appropriate sugar nucleotides and acceptors (35, 36); conversely, highly purified rabbit glycogen synthetase (35) and bovine milk lactose synthetase (36) do not show arylhexosidase activity. ${ }^{6}$

Mammalian glycosidases occurring in liver and kidney have been suggested to play a significant role in detoxification of plant glycosides (37). Arylhexosidase, which catalyzes the hydrolysis of plant aryl glucosides, may serve this function. Indeed, the potent physiological action of phloridzin on sugar transport (38) might be partially explained by the limited cleavage of this plant glycoside by liver and kidney arylhexosidasc.

Indirect evidence has been obtained that may link arylhexosidase-like activity with sugar transport. This relationship is suggested by: the histochemical demonstration of high levels of a $\beta$-galactosidase resembling arylhexosidase in the proximal convoluted tubules of rat kidney (39); the interaction of porcine kidney $\beta$-glucosidase with phloridzin at levels that inhibit sugar transport (28); the presence of arylhexosidase-like activity in tissues that have a high capacity for sugar transport (29); and the observation that aryl glycosides of the specific sugars transported are hydrolyzed by arylhexosidase (29). In the present study, the presence of arylhexosidase in bovine liver, kidney, and intestine has been confirmed by a specific assay procedure. Arylhexosidase was shown to interact with phloridzin to produce increased $\beta$-galactosidase activity and decreased $\beta$ glucosidase activity (Table III). In addition, phloridzin was an efficient acceptor for glycosyl residues in arylhexosidase-cat-

\footnotetext{
${ }^{6}$ Distler and Jourdian, unpublished observations.
}

alyzed transglycosylation reactions (Table IV). While these observations suggest a possible role of arylhexosidase in sugar transport, final judgment must await elucidation of the mechanism and control of this process.

\section{ACKNOWLEDGMENTS}

The skillful technical assistance of Mrs. Miriam Butsch, Mr. David Greenblatt, Miss Jana Laidlaw, and Mr. Millard Neymark is gratefully acknowledged.

\section{REFERENCES}

1. Distler, J. J., and Jourdian, G. W. (1973) $J$. Biol. Chem. 248, 6772-6780.

2. Jourdian, G. W., And Distler, J. (1973) in Proceedings of the Ninth International Congress on Biochemistry, Vol. 2, p. 18, Stockholm.

3. Robinson, D., Price, R. G., and Dance, N. (1967) Biochem. J. 102, 525-532.

4. Price, R. G., and Robinson, D. (1966) Comp. Biochem. Physiol. 17, 129-138.

5. Chytil, F. (1965) Biochem. Biophys. Res. Commun. 19, 630-636.

6. Hultberg, B., and Öckerman, P. A. (1969) Scand. J. Clin. Lab. Invest. 23, 213-217.

7. Heyworth, R., and Dahlqvist, A. (1962) Biochim. Biophys. Acta 64, 182-184.

8. Distler, J. (1976) Fed. Proc. 35, 1727.

9. Jourdian, G. W., and Distler, J. J. (1973) $J$. Biol. Chem. 248, 6781-6787.

10. KUm, K., ANd Roseman, S. (1966) Biochemistry 5, 3061-3065.

11. Jourdian, G. W., ANd Distler, J. J. (1972) Carbohyd. Res. 22, 369-379.

12. LI, Y.-T., AND LI, S.-C. (1972) in Methods in Enzymology, Vol. 28, pp. 714-720, Academic Press, New York.

13. Mcllvaine, T. C. (1921) J. Biol. Chem. 49, 183186.

14. Lowry, O. H., Rosebrough, N. J., Farr, A. L., AND RANDALl, R. J. (1951) J. Biol. Chem. 193, 265-275.

15. Weber, K., and Osborn, M. (1969) e. Biol. Chem. 244, 4406-4412.

16. ANDrews, P. (1964) Biochem. J. 91, 222-233.

17. Worthington Biochemical Corp. (1972) Worthington Enzyme Manual, p. 19, Freehold, N.J.

18. Öckerman, P. A. (1968) Biochim. Biophys. Acta 16., 59-62.

19. Patrick, A. D. (1965) Biochem. J. 97, 17c-18c.

20. WeinReb, N. J., AND Brady, R. O. (1972) in Methods in Enzymology, Vol. 28, pp. 830-834, Academic Press, New York.

21. Radin, N. S. (1972) in Methods in Enzymology, Vol. 28, pp. 834-839, Academic Press, New 
York.

22. RAdIN, N. S. (1972) in Methods in Enzymology, Vol. 28, pp. 844-847, Academic Press, New York.

23. Legler, G. (1966) Z. Physiol. Chem. 345, 197214.

24. Borgström, B., ANd Dahlqvist, A. (1958) Acta Chem. Scand. 12, 1997-2006.

25. Schachter, H., Jabbal, I., Hudgin, R. L., Pinteric, L., McGuire, E. J., and Roseman, S. (1970) J. Biol. Chem. 245, 1090-1100.

26. Ho, M. W., AND O'BrIEN, J. S. (1971) Clin. Chim. Acta 32, 443-450.

27. Robinson, D., and Abrahams, H. E. (1967) Biochim. Biophys. Acta 132, 212-214.

28. Abrahams, H. E., and Robinson, D. (1969) Biochem. J. 111, 749-755.

29. Glew, R. H., Peters, S. P., ANd Christopher, A. R. (1976) Biochim. Biophys. Acta 422, 179199.

30. Mellor, J. D., and Layne, D. S. (1971) J. Biol. Chem. 246, 4377-4380.

31. Schlegel-Haultek, S., Hore, P., Kekry, K.
R., AND Semenza, G. (1972) Biochim. Biophys. Acta 258, 506-519.

32. KramL, J., Kolínská, J. Ellederová, D., AND HrRšová, D. (1972) Biochim. Biophys. Acta 258, 520-530.

33. Heyworth, R., AND Dahlqvist, A. (1962) Biochim. Biophys. Acta 64, 182-184.

34. Hultberg, B., AND Ö́kerman, P. A. (1972) Clin. Chim. Acta 39, 49-58.

35. Villar-Palasi, C., Rosell-Perez, M., HizukURI, S., Huijing, F., and Larner, J. (1966) in Methods in Enzymology, Vol. 8, pp. 374384, Academic Press, New York.

36. Babad, H., ANd Hassid, W. Z. (1966) in Methods in Enzymology, Vol. 8, pp. 346-351, Academic Press, New York.

37. Wright, S. E. (1960) in The Metabolism of Cardiac Glycosides, p. 56, Charles C Thomas, Springfield, Ill.

38. Crane, R. K. (1960) Physiol. Rev . 40, 789-825.

39. Rutenburg, A. M., Rutenburg, S. H., Monis, B., Teague, R., and Seligman, A. M. (1958) J. Histochem. Cytochem. 6, 122-129. 